\title{
SOYBEAN (GLYCINE MAX(L.) MERR.) RESPONSE TO COMMERCIAL INOCULATION WITH BRADYRHIZOBIUM JAPONICUM
}

\author{
JARECKI, W. ${ }^{*}$ - BUCZEK, J. - JAŃCZAK-PIENIĄŻEK, M. \\ Department of Crop Production, University of Rzeszów, Rzeszów, Poland \\ ${ }^{*}$ Corresponding author \\ e-mail: waclaw.jarecki@wp.pl \\ (Received $2^{\text {nd }}$ May 2020; accepted $29^{\text {th }}$ Jul 2020)
}

\begin{abstract}
The symbiotic nitrogen fixation is used to maximum advantage in the case of leguminous crops. It is therefore important to inoculate seeds with relevant strains of bacteria before sowing especially if the crop is to be grown for the first time on the land. A field experiment was done to assess the effect of inoculation with Bradyrhizobium japonicum on the growth and yield performance of soybean. Soybean cultivars inoculated with Nitrazon had significantly greater nodule numbers and dry weight of nodules compared to un-inoculated control. The bacterial preparation increased plant lodging and extended their vegetation period. Nitrazon had a positive effect on the number of pods per plant and thousand seed weight. The obtained increase in seed yield was $0.54 \mathrm{t}^{-} \mathrm{ha}^{-1}$ compared to the control. Measurements of soil plant analysis development (SPAD) and leaf area index (LAI) showed that the plants were better nourished and had a higher green mass after Nitrazon application. Seed inoculation did not modify the leaf stomatal conductance (Gs). Nitrazon increased total protein content in seeds. The tested parameters were significantly diversified between cultivars and in the years of the study.
\end{abstract}

Keywords: nitrogen fixation, soil plant analysis development, leaf stomatal conductance, leaf area index, yield

\section{Introduction}

Soybean is one of the most economically important crops in the world, which results from the high value of its seeds and their versatile use. Soybean production is low in the European Union, but interest in growing this valuable plant has increased in recent years. Watson et al. (2017) reported that this was due to the growing demand for plant protein and the introduction of new high-yielding cultivars with good food and feed seed value. In soybean cultivation, inoculation of sowing material with bacteria fixing free nitrogen from the air is an especially important procedure (Gwata et al., 2004; Dwivedi et al., 2015; Vargas-Díaz et al., 2019). This treatment is particularly recommended when native strains of symbiotic bacteria are not present in the soil or there are too few of them (Solomon et al., 2012; Marinković et al., 2017; Jarecki, 2020). A good solution in this case may be the purchase for sowing material industrially inoculated with symbiotic bacteria (Flajšman et al., 2019) or the purchase of a commercial inoculant and its application to seeds (Kozieł et al., 2013; Pannecoucque et al., 2018). According to Deaker et al. (2004), increasing the amount of inoculant above the commercially recommended dose did not pose a threat and even caused a linear increase in nodulation and yield. Coskan and Dogan (2011) showed that the shape and size of nodules was characteristic of individual legumes. Nodules on soybean roots are usually round and the most effective are the large ones reddish in color inside (Fig. 1). 


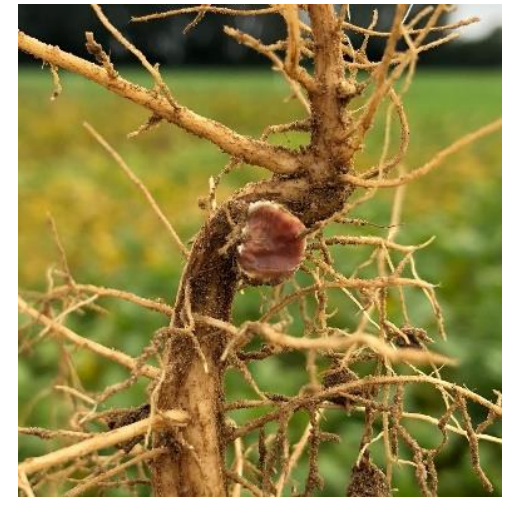

a

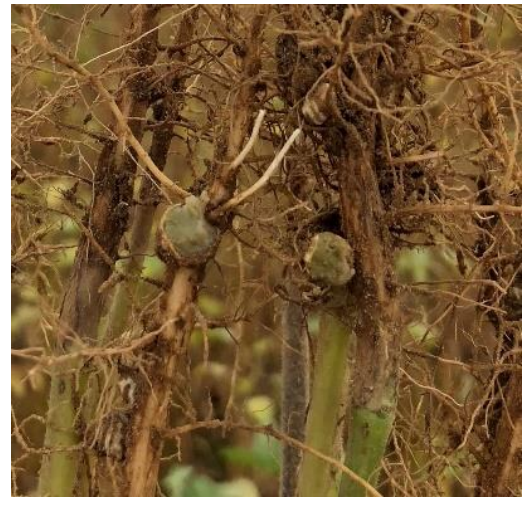

$\mathrm{b}$

Figure 1. Cross-section of bacterial nodules on soybean root, $a$-active, $b$ - inactive (W. Jarecki)

Numerous studies (Althabegoiti et al., 2008; López-García et al., 2009; Abou-Shanab et al., 2017) have demonstrated that the occurrence of Rhizobium bacteria in soil is common in some regions. In such case, inoculation with commercial preparations may be less effective, because native Rhizobium strains are competitive in establishing symbiosis (Wongphatcharachai et al., 2015; Onishchuk et al., 2017; Iturralde et al., 2019). Torres et al. (2012) also emphasized the need for periodic evaluation of commercial bacterial cultures to guarantee effective symbiosis after seed inoculation. Zhang et al. (2011) indicated in this aspect a high biodiversity and often a unique distribution of Rhizobium communities in individual regions. Giongo et al. (2008) demonstrated a high level for genetic diversity of Bradyrhizobium bacteria, which nodulate soybean in the fields. This information may be useful in experiments on new commercial inoculants better adapted to local environmental conditions. Shiro et al. (2013) observed that Bradyrhizobium japonicum and Bradyrhizobium elkanii, but also others, are the main Rhizobia nodulating soybeans. Studies by Thilakarathna and Raizad (2017) have shown that local strains of nitrogen-fixing bacteria are often better adapted to local conditions of environmental stress, suggesting great potential for their commercialization. With proper nodulation, soybean plant demand for nitrogen is met at 40-57\% (Zimmer et al., 2016) and even up to $60 \%$ (Salvagiotti et al., 2008) by biological $\mathrm{N}_{2}$ fixing. In the discussed case, the need for soybean mineral nitrogen fertilization is ambiguous, especially with proper nodulation (Salvagiotti et al., 2008). Some studies indicated that soybean plants responded favorably to small doses of mineral nitrogen, e.g. in worse environmental conditions (Aboutalebian and Malmir, 2017; Cafaro La Menza et al., 2017; Gai et al., 2017). In turn, Albareda et al. (2009) and Kaschuk et al. (2016) reported that mineral soybean nitrogen fertilization was superfluous in case of proper symbiosis. This also applied to new high-yielding cultivars. Many reports (Zimmer et al., 2016; Leggett et al., 2017; Adjetey and Mbotho, 2019) showed that the use of seed inoculation significantly increased soybean yield compared to controls. In contrast, Abou-Shanab et al. (2017) and Ambrosini et al. (2019) reported that inoculation did not always increase soybean seed yield. The effect of using commercial biological preparations depends on many factors (Abou-Shanab et al., 2017; Kühling et al., 2018; Adjetey and Mbotho, 2019). Suzuki et al. (2014) examined Bradyrhizobium japonicum and Bradyrhizobium elkanii and showed that the former were more effective at lower temperatures. Interesting results were presented by López-García et al. (2009), which showed that the improvement of soybean nodulation resulted in a 
low, insignificant increase in yield, and nitrogen content in seeds did not change. Albareda et al. (2009) and Narożna et al. (2015) presented imortant studies on the survival of Rhizobium strains in soil in the successive years following soybean cultivation.

The purpose of this research was to determine the influence of nitrogen fixing bacteria on the growth and grain yield of some soybean cultivars, from different maturity groups, in the field conditions of South-East Poland.

\section{Materials and methods}

This study was conducted an individual farm in Makowisko $\left(50^{\circ} 3^{\prime} \mathrm{N} 22^{\circ} 47^{\prime} \mathrm{E}\right)$, Podkarpackie Voivodeship, Poland (Fig. 2), in the years 2017-2019.

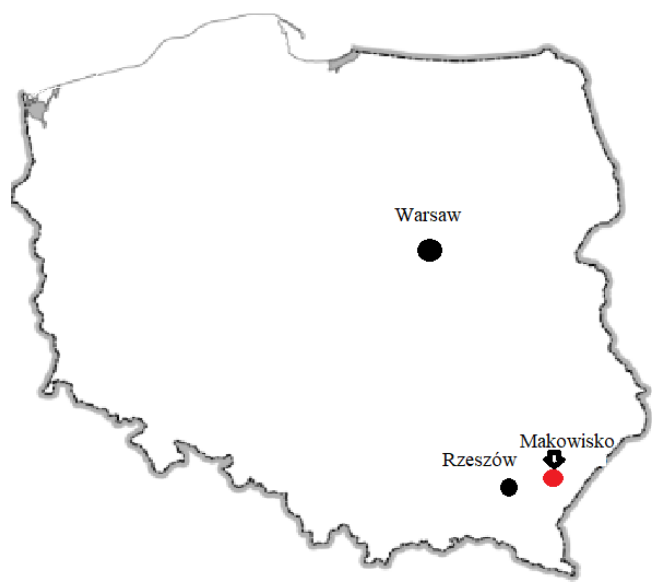

Figure 2. Location of field experiment

The first factor in the experiment was the Nitrazon biological preparation containing Bradyrhizobium japonicum and a control object - without inoculation. The second factor was soybean cultivars (main plots): Annushka, Lajma, Madlen, Violetta, Atlanta and Smuglyanka (AgeSoya Sp. z o.o., Poland). The cultivars are a high-yieldings recommended for cultivation in the area of the study. The experiment was carried out in four replications in a split-plot design. No soybean was previously grown in the experimental field. Seeds were inoculated according to the manufacturer recommendations (Farma Žiro Ltd., Czech Republic). Inoculation was done just prior to sowing.

The experiment was established on sandy loam soil, Haplic Luvisol (Food and Agriculture Organization of the United Nations, 2015). It was good wheat soil complex. Detailed descriptions of the soil characteristics are given in Table 1. Soil sample analysis was carried out at the District Chemical-Agricultural Station in Rzeszów.

Table 1. Chemical soil properties before the experiment $(0-60 \mathrm{~cm})$

\begin{tabular}{|c|c|c|c|c|c|c|}
\hline \multirow{2}{*}{ Years } & \multirow{2}{*}{ Humus \% } & \multirow{2}{*}{$\underset{1 \mathrm{pH}}{1 \mathrm{~mol} / \mathrm{L} \mathrm{KCl}}$} & \multirow{2}{*}{$\underset{\mathrm{kg} \mathrm{ha}^{-1} \mathrm{DM}}{\mathrm{Nmin}}$} & $\mathbf{P}_{2} \mathbf{O}_{5}$ & $\mathbf{K}_{2} \mathbf{O}$ & Mg \\
\hline & & & & \multicolumn{3}{|c|}{ mg $100 \mathrm{~g}^{-1}$ of soil } \\
\hline 2017 & 1.78 & 6.19 & 59.4 & 27.2 & 35.1 & 3.7 \\
\hline 2018 & 1.71 & 5.92 & 55.1 & 23.8 & 24.1 & 2.8 \\
\hline 2019 & 2.34 & 5.89 & 63.0 & 31.6 & 28.6 & 4.9 \\
\hline
\end{tabular}


Weather conditions are given according to meteorological data of the Experimental Stations for Variety Testing in Skołoszów. Distance from the experimental field about $12 \mathrm{~km}$.

Sowing of seeds was carried out in the first days of May. The single plot area was $15 \mathrm{~m}^{2}$. Soybeans were sown with 60 kernels capableof germination per $\mathrm{m}^{2}$ and a space between rows of $45 \mathrm{~cm}$. Winter wheat served as the forecrop.

NPK fertilization and plant protection treatments are described in detail in the publication Jarecki (2020).

Plant development stages are given according to the $\mathrm{BBCH}$ scale (Biologische Bundesanstalt, Bundessortenamtund CHemische Industrie). The full maturity stage of plants $(\mathrm{BBCH})$ was given in days from the date of sowing. Plant lodging assessed before harvest on a scale of $1-9^{\circ}\left(1^{\circ}-\right.$ the highest plant lodging, $9^{\circ}-$ no lodging $)$. The measurement of stomatal conductance of leaves (Gs) was performed with a Meter Porometr SC-1 apparatus (Pullman, USA). Soil plant analysis development (SPAD) was measured with a SPAD 502P chlorophylometer (Konica Minolta, Inc. Japan). Leaf area index (LAI) measurements was performed using a Meter LP-80 AccuPAR apparatus (Pullman, USA). Gs, SPAD and LAI were measured in the BBCH 70 stage.

To assess nodulation parameters, in the flowering stage (BBCH 65), 20 roots were randomly collected from one plot. Then in laboratory the number and dry weight of the nodules were determined.

At physiological maturity stage, 25 plants were collected for measuring the number of pods per plant and thousand seed weight $(\mathrm{g})$. Seed yield obtained from the plots (BBCH 89 ) was converted into a yield per 1 ha with a moisture content of $15 \%$.

The chemical composition of seeds was determined with the near-infrared spectroscopy (NIRS) method using an FT NIR MPA spectrometer (Bruker, Billerica, USA).

The significance of differences between the characteristic values was found based on Tuckey's halfconfidence intervals, with the significance level $p=0.05$. Calculations were made using the software Statistica 10 PL (Stat Soft, Inc., Tulsa, USA).

\section{Results and discussion}

The weather conditions in 2017-2019 differed from the long-term average. In region, mean annual precipitation is $673 \mathrm{~mm}$ and mean annual temperature is $8.4^{\circ} \mathrm{C}$. The detailed description of the climatic conditions is given in the Table 2.

Table 2. Weather conditions in the years 2017-2019

\begin{tabular}{c|c|c|c|c|c|c|c|c}
\hline \multirow{2}{*}{ Months } & \multicolumn{4}{|c|}{ Mean temperature $\left({ }^{\circ} \mathbf{C}\right)$} & \multicolumn{4}{c}{ Sum of precipitation (mm) } \\
\cline { 2 - 9 } & $\mathbf{2 0 1 7}$ & $\mathbf{2 0 1 8}$ & $\mathbf{2 0 1 9}$ & $1978-2015$ & $\mathbf{2 0 1 7}$ & $\mathbf{2 0 1 8}$ & $\mathbf{2 0 1 9}$ & $1978-2015$ \\
\hline April & 6.4 & 10.9 & 7.3 & 9.0 & 42.7 & 24.3 & 46.7 & 46.0 \\
May & 12.6 & 14.9 & 11.8 & 14.1 & 68.4 & 47.0 & 158.6 & 71.6 \\
June & 17.3 & 17.0 & 19.5 & 16.6 & 48.7 & 104.7 & 25.4 & 79.2 \\
July & 18.0 & 18.5 & 17.9 & 18.5 & 43.0 & 98.1 & 60.2 & 94.3 \\
August & 18.4 & 18.4 & 17.7 & 18.1 & 21.2 & 84.3 & 101.9 & 63.0 \\
September & 12.5 & 12.9 & 12.7 & 13.4 & 102.5 & 34.6 & 33.7 & 62.5 \\
October & 8.3 & 7.3 & 8.1 & 8.8 & 58.4 & 40.1 & 37.9 & 47.7 \\
\hline
\end{tabular}


The number of nodules and the dry weight of nodules were significantly higher after the use of bacterial inoculant compared with the control (Table 3). On average, 19.9 nodules were found on a single soy root after inoculation Nitrazon, and 0.52 nodules on a un-inoculated control. The highest number of nodules and their highest dry weight were obtained in cultivars Lajma (Fig. 3) and Atlanta. The weather conditions had a significant impact on soybean nodulation. In 2018, an average of 14.6 nodules were recorded per root. The fewest nodules and their lowest dry weight were obtained in 2017.

Table 3. Impact of seed inoculation on nodulation, lodging and maturity of plants

\begin{tabular}{|c|c|c|c|c|}
\hline Specification & $\begin{array}{c}\text { The number of } \\
\text { nodules }\end{array}$ & $\begin{array}{c}\text { The dry weight of } \\
\text { nodules (g) }\end{array}$ & $\begin{array}{c}\text { Lodging } \\
\left(1-9^{\circ}\right) \\
\end{array}$ & \begin{tabular}{|c} 
Maturity (number of days \\
since sowing)
\end{tabular} \\
\hline \multicolumn{5}{|c|}{ Inoculation } \\
\hline Control & $0.52^{\mathrm{b}}$ & $0.04^{\mathrm{b}}$ & $8.4^{\mathrm{a}}$ & $136^{\mathrm{a}}$ \\
\hline Nitrazon & $19.9^{\mathrm{a}}$ & $0.71^{\mathrm{a}}$ & $7.9^{\mathrm{b}}$ & $138^{\mathrm{a}}$ \\
\hline \multicolumn{5}{|c|}{ Cultivar } \\
\hline Annushka & $10.0^{\mathrm{ab}}$ & $0.41^{\mathrm{ab}}$ & $8.3^{\mathrm{ab}}$ & $123^{c}$ \\
\hline Lajma & $12.8^{\mathrm{a}}$ & $0.54^{\mathrm{a}}$ & $8.6^{\mathrm{a}}$ & $128^{\mathrm{c}}$ \\
\hline Madlen & $8.7^{\mathrm{bc}}$ & $0.23^{\mathrm{c}}$ & $7.9^{\mathrm{bc}}$ & $138 b^{c}$ \\
\hline Violetta & $7.5^{\mathrm{c}}$ & $0.21^{\mathrm{c}}$ & $8.6^{\mathrm{a}}$ & $137 b^{c}$ \\
\hline Atlanta & $12.7^{\mathrm{a}}$ & $0.52^{\mathrm{a}}$ & $8.0^{\mathrm{bc}}$ & $145^{\mathrm{ab}}$ \\
\hline Smuglanka & $9.5^{\mathrm{bc}}$ & $0.34^{\mathrm{bc}}$ & $7.6^{\mathrm{c}}$ & $151^{\mathrm{a}}$ \\
\hline \multicolumn{5}{|c|}{ Year } \\
\hline 2017 & $6.36^{\mathrm{c}}$ & $0.21^{\mathrm{c}}$ & $8.7^{\mathrm{a}}$ & $128^{\mathrm{b}}$ \\
\hline 2018 & $14.6^{\mathrm{a}}$ & $0.54^{\mathrm{a}}$ & $7.7^{\mathrm{c}}$ & $145^{\mathrm{a}}$ \\
\hline 2019 & $9.65^{b}$ & $0.37^{\mathrm{b}}$ & $8.1^{\mathrm{ab}}$ & $138^{\mathrm{ab}}$ \\
\hline
\end{tabular}

Average values for each factor marked with different letters in a column differ significantly $(\mathrm{P}<0.05)$

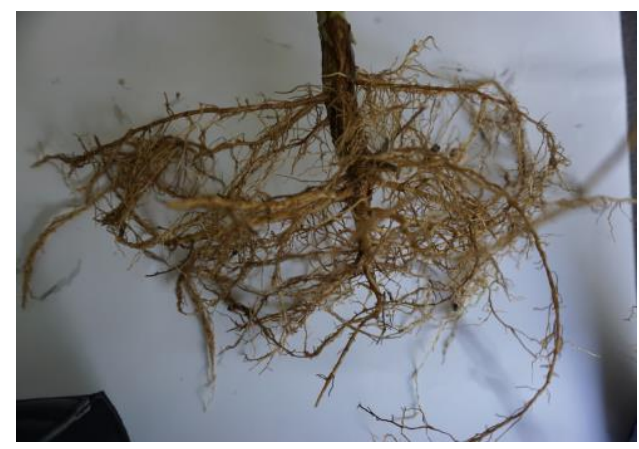

a

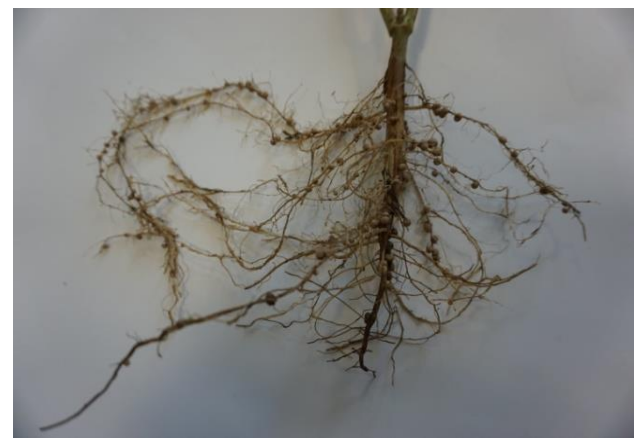

b

Figure 3. Lajma cultivar, $a$-without inoculation, $b$ - with inoculation (W. Jarecki)

Althabegoiti et al. (2008) reported that commercial soybean inoculant could be used on seeds or in the soil, in which they would be sown. These authors obtained better results in the latter case. Zerpa et al. (2013) obtained the highest number of nodules on soybean roots (17.5 on average) after combined use of two commercial bacterial strain. Nodulation was not found in the control object. Adjetey and Mbotho (2019) demonstrated the efficacy of commercial inoculates, and observed few nodules in control plants. Abou-Shanab et al. (2017) concluded that the presence of native strains of Rhizobium bacteria in soil also 
caused nodulation on non-inoculated roots (control). The obtained results of soybean seed inoculation by the above-mentioned authors varied depending on the bacterial strain, soil nitrogen content, cultivar and study region. Thuita et al. (2012) report that both the number of nodules on the roots and their weight are significantly dependent on the inoculant used. At the same time, the obtained results were also heavily influenced by the cultivar. Marinković et al. (2018) obtained a varied number and dry weight of nodules on soybean roots depending on the strain of symbiotic bacteria. This provided the basis for selecting the best one for the production of commercial preparations.

In the present study, the application of Nitrazon significantly increased lodging of the plants compared to control. The difference obtained was $0.5^{\circ}$. Plants of the cultivar Smuglanka were characterized by the greatest lodging. Annushka, Lajma and Violetta cultivars were significantly less affected by lodging. In the years of research, the discussed parameter significantly differed. In 2018, plant lodging was the greatest and amounted to $7.7^{\circ}$. The bacterial strain extended the vegetation period by an average of two days compared to control, but this has not been statistically proven. The vegetation period of the studied cultivars ranged from 123 days in the cultivar Annushka to 151 days in the cultivar Smuglanka. Differences in the studied parameter were recorded during the years of the study. Soybean plants reached full maturity after 128 days in 2017 and 145 days in 2018.

The bacterial preparation has significantly increased the number of pods per plant and thousand seed weight. The obtained increase in seed yield was $16.9 \%$ compared with the control (Table 4). Madlen, Atlanta and Smuglanka were high yielding cultivars. The cultivar Lajma produced a significantly lower seed yield. Seed yield in 2018 was $3.65 \mathrm{t} \cdot \mathrm{ha}^{-1}$, while in $2017-3.27 \mathrm{t} \cdot \mathrm{ha}^{-1}$. Therefore, the obtained difference amounted to $11.6 \%$.

Table 4. Yield and yield components

\begin{tabular}{|c|c|c|c|}
\hline Specification & Yield $\left(t \cdot h^{-1}\right)$ & The number of pods per plant & Thousand seed weight (g) \\
\hline \multicolumn{4}{|c|}{ Inoculation } \\
\hline Control & $3.19^{\mathrm{b}}$ & $29.6^{\mathrm{b}}$ & $147.9^{\mathrm{b}}$ \\
\hline Nitrazon & $3.73^{\mathrm{a}}$ & $34.1^{\mathrm{a}}$ & $153.1^{\mathrm{a}}$ \\
\hline \multicolumn{4}{|c|}{ Cultivar } \\
\hline Annushka & $3.39^{\mathrm{ab}}$ & $31.9^{\mathrm{ab}}$ & $145.6^{\mathrm{b}}$ \\
\hline Lajma & $3.35^{\mathrm{b}}$ & $30.8^{\mathrm{b}}$ & $147.5^{\mathrm{b}}$ \\
\hline Madlen & $3.56^{\mathrm{a}}$ & $31.2^{\mathrm{b}}$ & $161.8^{\mathrm{a}}$ \\
\hline Violetta & $3.39^{\mathrm{ab}}$ & $31.1^{\mathrm{b}}$ & $145.9^{\mathrm{b}}$ \\
\hline Atlanta & $3.54^{\mathrm{a}}$ & $32.9^{\mathrm{a}}$ & $155.4^{\mathrm{ab}}$ \\
\hline Smuglanka & $3.53^{\mathrm{a}}$ & $33.2^{\mathrm{a}}$ & $146.8^{\mathrm{b}}$ \\
\hline \multicolumn{4}{|c|}{ Year } \\
\hline 2017 & $3.27^{\mathrm{b}}$ & $32.8^{b}$ & $141,9^{b}$ \\
\hline 2018 & $3.65^{\mathrm{a}}$ & $37.9^{\mathrm{a}}$ & $156.4^{\mathrm{a}}$ \\
\hline 2019 & $3.46^{\mathrm{ab}}$ & $27.8^{\mathrm{c}}$ & $153.2^{\mathrm{a}}$ \\
\hline
\end{tabular}

Average values for each factor marked with different letters in a column differ significantly $(\mathrm{P}<0.05)$

Macák and Candráková (2013) reported that the number of pods per plant, thousand seed weight and seed yield of soybean were variable in years, while the number of seeds in the pod was stable. Căpățână et al. (2017) obtained an increase in soybean seed yield 
after inoculation, but only by $3.76 \%$ compared to control. Solomon et al. (2012) and Thuita et al. (2012) confirmed that not every strain of Bradyrhizobium japonicum provided the expected results. They also added that in the case of soybean, yielding was mainly determined by the selection of proper cultivar. Abou-Shanab et al. (2017) concluded that inoculation of legumes with nitrogen-fixing bacteria did not always result in a significant increase in seed yield. Therefore, recommendations for the use of biological preparations should be related to regional habitat conditions. This was also confirmed by the experiments carried out by Leggett et al. (2017), who showed that the effects of soybean seed inoculation with Bradyrhizobium japonicum varied depending on the years of research and the specificity of a given area.

On average, soybean seeds contained $37.5 \%$ protein and $19.5 \%$ fat. The applied Nitrazon significantly increased protein content in seeds. Crude fat content was not changed compared to control (Table 5). The tested cultivars had significantly different content of protein and fat in seeds. The highest total protein content was determined in seeds of the cultivar Violetta and crude fat in the seeds of the cultivars Lajma and Madlen. The chemical composition of seeds was varied during the years of the study.

Table 5. Chemical seed composition

\begin{tabular}{c|c|c}
\hline Specification & Protein total (\% DM) & Crude fat (\% DM) \\
\hline \multicolumn{3}{c}{ Inoculation } \\
\hline Control & $36.3^{\mathrm{b}}$ & $19.6^{\mathrm{a}}$ \\
Nitrazon & $38.7^{\mathrm{a}}$ & $19.4^{\mathrm{a}}$ \\
\hline \multicolumn{2}{c}{ Cultivar } \\
\hline Annushka & $37.2^{\mathrm{ab}}$ & $19.5^{\mathrm{ab}}$ \\
Lajma & $36.7^{\mathrm{b}}$ & $20.2^{\mathrm{a}}$ \\
Madlen & $37.7^{\mathrm{ab}}$ & $20.0^{\mathrm{a}}$ \\
Violetta & $38.6^{\mathrm{a}}$ & $19.4^{\mathrm{ab}}$ \\
Atlanta & $37.6^{\mathrm{ab}}$ & $18.9^{\mathrm{b}}$ \\
Smuglanka & $37.2^{\mathrm{ab}}$ & $19.0^{\mathrm{b}}$ \\
\hline \multicolumn{2}{c}{ Year } & $20.5^{\mathrm{a}}$ \\
\hline 2017 & $36.8^{\mathrm{b}}$ & $18.2^{\mathrm{b}}$ \\
2018 & $38.2^{\mathrm{a}}$ & $19.8^{\mathrm{ab}}$ \\
\hline
\end{tabular}

Average values for each factor marked with different letters in a column differ significantly $(\mathrm{P}<0.05)$

Zimmer et al. (2016) stated that the use of commercial bacterial strain in soybean cultivation was justified. At the same time, they obtained various effects in the form of an increase in protein yield depending on the study area. Pannecoucque et al. (2018) and Flajšman et al. (2019) reported that commercial preparations effectively increased soybean nodulation, which resulted in an increase in protein content in seeds and protein yield compared to control. Cafaro La Menza et al. (2017) concluded that obtaining high soybean yields, including protein yields, required adequate nitrogen supply. However, with high nitrogen availability, they noted a slight increase in protein content and a decrease in fat in soybean seeds.

Plant nutritional status assessed by the SPAD index was higher after Nitrazon application compared to control. Among the tested cultivars, Annushka was characterized by a high SPAD index, while Atlanta and Smuglanka the lowest. Significant differences in the SPAD index have been shown in plants between 2017 and 2018 (Fig. 4). 


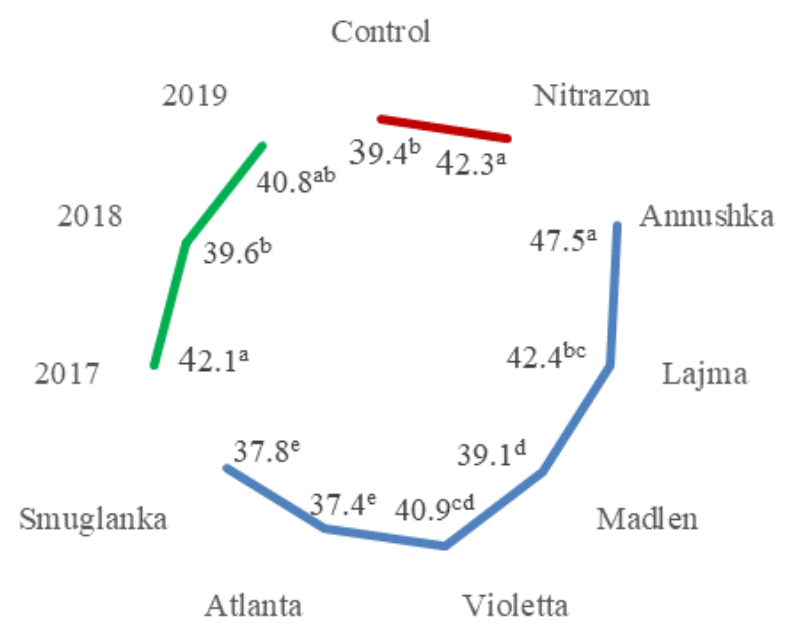

Figure 4. Soil plant analysis development (SPAD value)

Thompson et al. (1996) confirmed the usefulness of SPAD measurements for the assessment of chlorophyll content in soybean leaves, but the results were modified by environmental conditions. Fritschi and Ray (2007) believed that SPAD readings were useful, but should have also been supplemented with other measurement techniques. Kühling et al. (2018) reported that the SPAD value was higher after applying the inoculation procedure, but only at the beginning of soybean seed filling phase. In the research of Jarecki et al. (2016), better-fed plants (higher SPAD) were characterized by higher yields, which was confirmed by a strong correlation $(r=0.83)$. SPAD measurements can therefore be useful for predicting soybean seed yield. Vollmann et al. (2011) added that the assessment of chlorophyll content in leaves also allows to predict the quality parameters of soybean seeds.

Nitrazon significantly increased the LAI index compared to controls. Early cultivars (Annushka and Laima) were characterized by lower LAI values and late cultivars (Atlanta and Smuglanka) by its higher values. Differences in LAI were recorded during the years of the study. The highest LAI was recorded in 2017, while significantly lower in 2018 (Fig. 5).

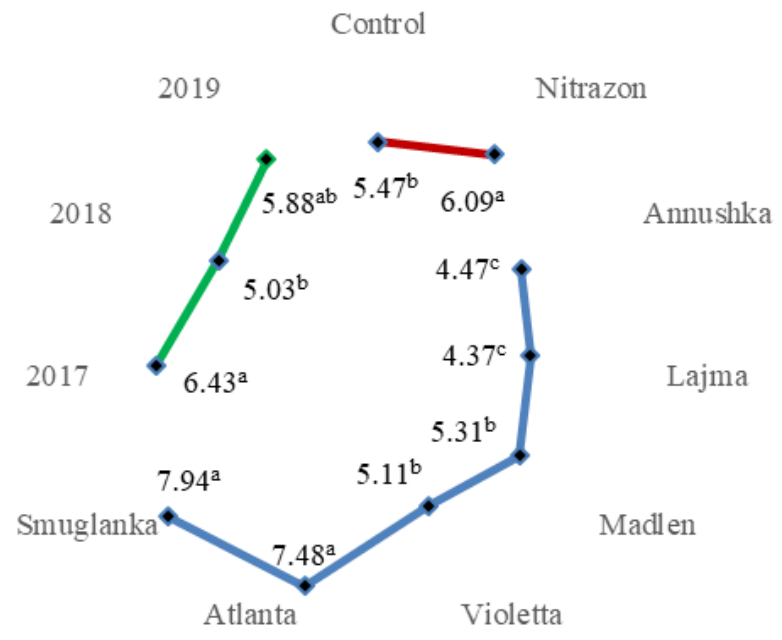

Figure 5. Leaf area index (LAI) 
Salvagiotti et al. (2008) have argued that the availability of nitrogen, which affects the growth and development of a single plant, largely determines soybean yield. Abou-Shanab et al. (2017) obtained a significantly higher dry weight of soybean plants after inoculation compared to control. However, seed yield did not increase significantly. Zerpa et al. (2013) showed an increase in soy leaf surface after the combined application of two commercial inoculant containing Bradyrhizobium japonicum. Single use of the test preparations was less effective. Adjetey and Mbotho (2019) obtained a greater number of leaves in the experiment with soybean after inoculation compared to control; nutrient uptake has also increased. Jarecki et al. (2016) reported that nitrogen availability for soybean plants increased the assimilation surface. However, they did not show a relationship between LAI measurements and seed yield.

The bacterial strain had no effect on leaf stomatal conductance (Gs) compared to control plants. The highest Gs had the cultivar Lajma and Violetta the lowest. In the years of the study, Gs ranged from 561 in 2019 to 836 in 2018 (Fig. 6).

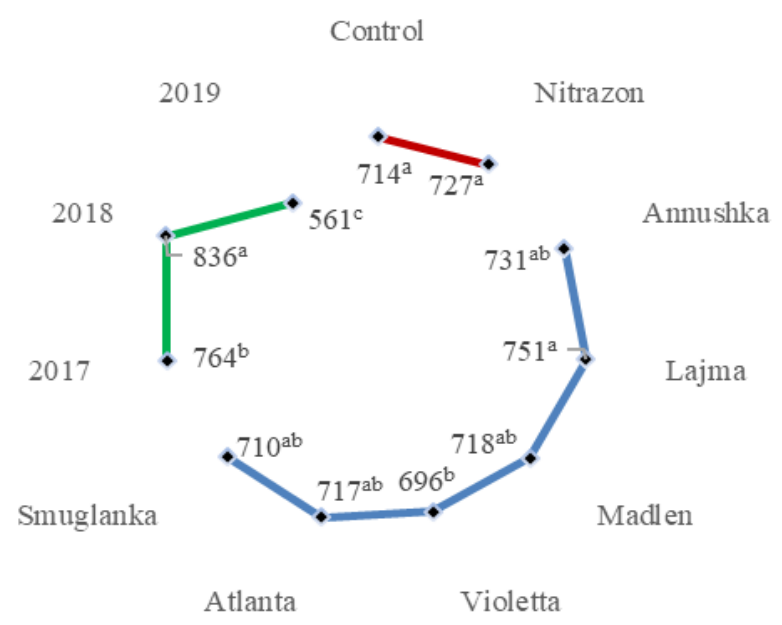

Figure 6. Leaf stomatal conductance (Gs)

$\mathrm{Yu}$ et al. (2018) believed that the results of leaf stomatal conductance were more accurate when carried out under controlled meteorological conditions compared to field conditions.

\section{Conclusion}

In this study, the use of commercial preparation - Nitrazon increased the number and dry weight of nodules on soybean roots compared to control. SPAD and LAI measurements showed that the use of Bradyrhizobium japonicum resulted in better nutrition and higher green mass of plants. The inoculation resulted in an increase in the number of pods per plant, thousand seed weight, seed yield, protein content in seeds compared to control. It was shown that the examined traits and parameters varied between cultivars and changed over the years of the study. Low seed yields were obtained in 2017 and high in 2018. Generally, inoculation of soybean seeds with nitrogen-fixing bacteria, can lead to a reduction of the consumption of nitrogen fertilizer in soybean cultivation. In next experiment, it is possible to assess the effectiveness of the commercial soybean seed coating with Bradyrhizobium japonicum. 
Funding. Project: Development of innovative biodegradable soybean seed coating based on biopolymers from renewable raw materials for better tolerance of plants to adverse environmental conditions (acronym: BIOSOYCOAT) is supported by the National Centre for Research and Development, within the framework of the strategic R\&D programme "Environment, agriculture and forestry" - BIOSTRATEG. Contract no. BIOSTRATEG3/346390/4/NCBR/2017. Duration of the project 2017-2020. The article processing charge was covered by the Ministry of Science and Higher Education of Poland. Project No.026/RID/2018/19 "Regional Initiative of Excellence", 2019-2022. Funding amount PLN 9542 500.00.

\section{REFERENCES}

[1] Abou-Shanab, R. A. I., Wongphatcharachai, M., Sheaffer, C. C., Orf, J. C., Sadowsky, M. J. (2017): Competition between introduced Bradyrhizobium japonicum strains and indigenous bradyrhizobia in Minnesota organic farming systems. - Symbiosis 73: 155-163.

[2] Aboutalebian, M. A., Malmir, M. (2017): Soybean yield and yield components affected by the mycorrhiza and bradyrhizobium at different rates of starter nitrogen fertilizer. - Semina: Ciênc. Agrár. 38: 2409-2418.

[3] Adjetey, J. A., Mbotho, K. (2019): Evaluation of Bradyrhizobium formulations on performance of soybean grown on soil without a long-term history of the crop. - Bots. J. Agric. Appl. Sci. 13: 66-70.

[4] Albareda, M., Rodriguea-Navarro, D. N., Temprano, F. J. (2009): Soybean inoculation: dose, $\mathrm{N}$ fertilizer supplementation and rhizobia persistence in soil. - Field Crops Res. 113: 352-356.

[5] Althabegoiti, M. J., López-García, S. L., Piccinetti, C., Mongiardini, E. J., Perez-Gimenez, J., Quelas, J. I., Perticari, A., Lodeiro, A. R. (2008): Strain selection for improvement of Bradyrhizobium japonicum competitiveness for nodulation of soybean. - FEMS Microbiol. Lett. 282: 115-123.

[6] Ambrosini, V. G., Fontoura, S. M. V., de Moraes, R. P., Tamagno, S., Ciampitti, I. A., Bayer, C. (2019): Soybean yield response to Bradyrhizobium strains in fields with inoculation history in Southern Brazil. - J. Plant Nutr. 42: 1941-1951.

[7] Cafaro La Menza, N., Monzon, J. P., Specht, J. E., Grassini, P. (2017): Is soybean yield limited by nitrogen supply? - Field Crop. Res. 213: 204-212.

[8] Căpățână, N., Bolohan, C., Marin, D. I. (2017): Research regarding the influence of mineral fertilization along with Bradyrhizobium japonicum on soybean grain yield (Glycine max (L.) Merrill), under the conditions of southeast Romania. - Sci. Papers. Ser. A. Agron. 60: 207-214.

[9] Coskan, A., Dogan, K. (2011): Symbiotic nitrogen fixation in soybean. - In: El-Shemy, H. A. (ed.) Soybean Physiology and Biochemistry. In Tech. 307: 167-182.

[10] Deaker, R., Roughley, R. J., Kennedy, I. R. (2004): Legume seed inoculation technology a review. - Soil Biol. Biochem. 36: 1275-1288.

[11] Dwivedi, S. L., Sahrawat, K. L., Upadhyaya, H. D., Mengoni, A., Galardini, M., Bazzicalupo, M., Biondi, E. G., Hungria, M., Kaschuk, G., Blair, M. W., Ortiz, R. (2015): Chapter One - Advances in host plant and Rhizobium genomics to enhance symbiotic nitrogen fixation in grain legumes. - Adv. Agron. 129: 1-116.

[12] Flajšman, M., Šantavec, I., Kolmanič, A., Kocjan Ačko, D. (2019): Bacterial seed inoculation and row spacing affect the nutritional composition and agronomic performance of soybean. - Int. J. Plant Prod. 13: 183-192.

[13] Food and Agriculture Organization of the United Nations. (2015): World reference base for soil resources 2014. - FAO, Rome, Italy. World Soil Resources Reports 106: 193.

[14] Fritschi, F. B., Ray, J. D. (2007): Soybean leaf nitrogen, chlorophyll content, and chlorophyll a/b ratio. - Photosynthetica 45: 92-98.

[15] Gai, Z., Zhang, J., Li, C. (2017): Effects of starter nitrogen fertilizer on soybean root activity, leaf photosynthesis and grain yield. - PLoS One 12: e0174841. 
[16] Giongo, A., Ambrosini, A., Vargas, L. K., Freire, J. R. J., Bodanese-Zanettini, M. H., Passaglia, L. M. P. (2008): Evaluation of genetic diversity of bradyrhizobia strains nodulating soybean [Glycine max (L.) Merrill] isolated from South Brazilian fields. - Appl. Soil Ecol. 38: 261-269.

[17] Gwata, E. T., Wofford, D. S., Pfahler, P. L., Boote, K. J. (2004): Genetics of promiscuous nodulation in soybean: nodule dry weight and leaf color score. - J. Hered. 95: 154-157.

[18] Iturralde, E. T., Covelli, J. M., Álvarez, F., Pérez-Giménez, J., Arrese-Igor, C., Lodeiro, A. R. (2019): Soybean-nodulating strains with low intrinsic competitiveness for nodulation, good symbiotic performance, and stress-tolerance isolated from soybean-cropped soils in Argentina. - Front. Microbiol. 10: 1061.

[19] Jarecki, W., Buczek, J., Bobrecka-Jamro, D. (2016): Response of soybean (Glycine max (L.) Merr.) to bacterial soil inoculants and foliar fertilization. - Plant Soil Environ. 62: 422427.

[20] Jarecki, W. (2020): Reaction of soybean [Glycine $\max$ (L.) Merr.] to seed inoculation with Bradyrhizobium japonicum bacteria. - Plant, Soil and Environment 66: 242-247.

[21] Kaschuk, G., Nogueira, M. A., de Luca, M. J., Hungria, M. (2016): Response of determinate and indeterminate soybean cultivars to basal and topdressing $\mathrm{N}$ fertilization compared to sole inoculation with Bradyrhizobium. - Field Crop. Res. 195: 21-27.

[22] Kozieł, M., Gębala, B., Martyniuk, S. (2013): Response of soybean to seed inoculation with Bradyrhizobium japonicum and with mixed inoculants of B. japonicum and Azotobacter chroococcum. - Pol. J. Microbiol. 62: 457-460.

[23] Kühling, I., Hüsing, B., Bome, N., Trautz, D. (2018): Soybeans in high latitudes: effects of Bradyrhizobium inoculation in northwest Germany and southern west Siberia. - Org. Agric. 8: 159-171.

[24] Leggett, M., Diaz-Zorita, M., Koivunen, M., Bowman, R., Pesek, R., Stevenson, C., Leister, T. (2017): Soybean response to inoculation with in the United States and Argentina. - Agron. J. 109: 1031-1038.

[25] López-García, S. L., Perticari, A., Piccinetti, C., Ventimiglia, L., Arias, N., DeBattista, J. J., Althabegoiti, M. J., Mongiardini, E. J., Pérez-Giménez, J., Quelas, J. I., Lodeiro, R. (2009): In-Furrow inoculation and selection for higher motility enhances the efficacy of Bradyrhizobium japonicum nodulation. - Agron. J. 101: 357-363.

[26] Macák, M., Candráková, E. (2013): The effect of fertilization on yield components and quality parameters of soybeans [(Glycine $\max ($ L.) Merr.)] seeds. - J. Cent. Eur. Agric. 14: 1232-1242.

[27] Marinković, J. B., Bjelić, D. Đ., Tintor, B. B., Ignjatov, M. V., Nikolić, Z. T., Đukić, V. H., Balešević-Tubić, S. N. (2017): Molecular identification of Bradyrhizobium japonicum strains isolated from root nodules of soybean (Glycine max L.). - Matica Srpska J. Nat. Sci. 132: 49-56.

[28] Marinković, J., Bjelić, D., Tintor, B., Miladinović, J., Đukić, V., Đorđević, V. (2018): Effects of soybean co-inoculation with plant growth promoting rhizobacteria in field trial. - Rom. Biotech. Lett. 23: 13401-13408.

[29] Narożna, D., Pudełko, K., Króliczek, J., Golińska, B., Sugawara, M., Mądrzak, C. J., Sadowsky, M. J. (2015): Survival and competitiveness of Bradyrhizobium japonicum strains 20 years after introduction into field locations in Poland. - Appl. Environ. Microbiol. 81: 5552-5559.

[30] Onishchuk, O. P., Vorobyov, N. I., Provorov, N. A. (2017): Nodulation competitiveness of nodule bacteria: genetic control and adaptive significance: Review. - Appl. Biochem. Microbiol. 53: 131-139.

[31] Pannecoucque, J., Goormachtigh, S., Ceusters, J., Debode, J., Van Waes, C., Van Waes, J. (2018): Temperature as a key factor for successful inoculation of soybean with Bradyrhizobium spp. under cool growing conditions in Belgium. - J. Agric. Sci. 156: 493503. 
[32] Salvagiotti, F., Cassman, K. G., Specht, J. E., Walters, D. T., Weiss, A., Dobermann, A. (2008): Nitrogen uptake, fixation and response to fertilizer $\mathrm{N}$ in soybeans: a review. - Field Crop. Res. 108: 1-13.

[33] Shiro, S., Matsuura, S., Saiki, R., Sigua, G. C., Yamamoto, A., Umehara, Y., Hayashi, M., Saeki, Y. (2013): Genetic diversity and geographical distribution of indigenous soybeannodulating bradyrhizobia in the United States. - Appl. Environ. Microbiol. 79: 3610-3618.

[34] Solomon, T., Pant, L. M., Angaw, T. (2012): Effects of inoculation by Bradyrhizobium japonicum strains on nodulation, nitrogen fixation, and yield of soybean (Glycine max $\mathrm{L}$. Merill) varieties on Nitisols of Bako, western Ethiopia. - Int. Sch. Res. Not., Article ID: 261475.

[35] Suzuki, Y., Adhikari, D., Itoh, K., Suyama, K. (2014): Effects of temperature on competition and relative dominance of Bradyrhizobium japonicum and Bradyrhizobium elkanii in the process of soybean nodulation. - Plant Soil 374: 915-924.

[36] Thilakarathna, M. S., Raizada, M. N. (2017): A meta-analysis of the effectiveness of diverse rhizobia inoculants on soybean traits under field conditions. - Soil Biol. Biochem. 105: 177-196.

[37] Thompson, J. A., Schweitzer, L. E., Nelson, R. L. (1996): Association of specific leaf weight, an estimate of chlorophyll, and chlorophyll concentration with apparent photosynthesis in soybean. - Photosynth. Res. 49: 1-10.

[38] Thuita, M., Pypers, P., Herrmann, L., Okalebo, R. J., Othieno, C., Muema, E., Lesueur, D. (2012): Commercial rhizobial inoculants significantly enhance growth and nitrogen fixation of a promiscuous soybean variety in Kenyan soils. - Biol. Fertil. Soils. 48: 87-96.

[39] Torres, A. R., Kaschuk, G., Saridakis, G. P., Hungria, M. (2012): Genetic variability in Bradyrhizobium japonicum strains nodulating soybean [Glycine max (L.) Merrill]. - World J. Microbiol. Biotechnol. 28: 1831-1835.

[40] Vargas-Díaz, A. A., Ferrera-Cerrato, R., Silva-Rojas, H. V., Alarcón, A. (2019): Isolation and evaluation of endophytic bacteria from root nodules of Glycine max L. (Merr.) and their potential use as biofertilizers. - Span. J. Agric. Res. 17: e1103.

[41] Vollmann, J., Walter, H., Sato, T., Schweiger, P. (2011): Digital image analysis and chlorophyll metering for phenotyping the effects of nodulation in soybean. - Comput. Electron. Agric. 75: 190-195.

[42] Watson, C. A., Reckling, M., Preissel, S., Bachinger, J., Bergkvist, G., Kuhlman, T., Lindström, K., Nemecek, T., Topp, C. F. E., Vanhatalo, A., Zander, P., Murphy-Bokern, D., Stoddard, F. L. (2017): Chapter Four - Grain legume production and use in European agricultural systems. - Adv. Agron. 144: 235-303.

[43] Wongphatcharachai, M., Staley, C., Wang, P., Moncada, K. M., Sheaffer, C. C., Sadowsky, M. J. (2015): Predominant populations of indigenous soy-bean nodulating Bradyrhizobium japonicum strains obtained from organic farming systems in Minnesota. - J. Appl. Microbiol. 118: 1152-1164.

[44] Yu, M., Ding, G., Gao, G., Zhao, Y., Sai, K. J. F. (2018): Leaf temperature fluctuations of typical psammophytic plants and their application to stomatal conductance estimation.Forests 9: 313.

[45] Zerpa, M., Mayz, J., Mendez, J. (2013): Effects of Bradyrhizobium japonicum inoculants on soybean (Glycine $\max$ (L.) Merr.) growth and nodulation. - Ann. Biol. Res. 4: 193-199.

[46] Zhang, Y. M., Li, Y. Jr., Chen, W. F., Wang, E. T., Tian, C. F., Li, Q. Q., Zhang, Y. Z., Sui, X. H., Chen, W. X. (2011): Biodiversity and biogeography of rhizobia associated with soybean plants grown in the North China Plain. - Appl. Environ. Microbiol. 77: 63316342.

[47] Zimmer, S., Messmer, M., Haase, T., Piepho, H. P., Mindermann, A., Schulz, H., Habekuß, A., Ordon, F., Wilbois, K. P., Heß, J. (2016): Effects of soybean variety and Bradyrhizobium strains on yield, protein content and biological nitrogen fixation under cool growing conditions in Germany. - Eur. J. Agron. 72: 38-46. 